\title{
Effect of cognitive social skills training on positive relationships with others and adjustment of students
}

\author{
Leila Kabiri" ${ }^{*}$ iD , Omid Shokri², Hossein Pourshahriar ${ }^{3}$
}

1. MA in Educational Psychology, Faculty of Psychology and Education, Shahid Beheshti University, Tehran, Iran

2. Assistant Professor in Educational Psychology, Department of Psychology, Faculty of Psychology and Education, Shahid Beheshti University, Tehran, Iran

3. Assistant Professor in Psychology, Department of Psychology, Faculty of Psychology and Education, Shahid Beheshti University, Tehran, Iran

Recieved: 4 Oct. 2018

Revised: 8 Jan. 2019

Accepted: 23 Jan. 2019

Keywords

Interpersonal relationship skills

Adjustment

Social cognition skills

Social competenceg

\section{Corresponding author}

Leila Kabiri, MA in Educational Psychology, Faculty of Psychology and Education, Shahid Beheshti University, Tehran, Iran

Email: L.kabiri.2525@gmail.com

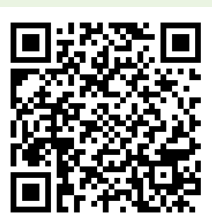

\section{Abstract}

Introduction: Psychologists and behavioral science experts have always tried to increase the level of adjustment of individuals in different age groups by various developing educational programs. Therefore, the review of the results of studies in the field of social cognition illustrates that a significant part of the cognitive social maltreatment of adolescents is related to the deficiency of their skill treasury. Hence, the purpose of this study was to examine the effectiveness of cognitive social skills training in positive relationships with others and adjustment of adolescents.

Methods: In this quesi-experimental research with pretest-posttest nonequivalent-group design with two month follow-up, a population of 148 female students of the 8th grade, 58 students were selected by convenience sampling method and then divided into two groups. All the participants in the two groups responded to the Scale of Positive Relationships with Others and Student Adjustment Inventory for School Students before and after the experiment. The students of the experimental group received cognitive social skills training for 10 weeks, ( 2 hours per week). Finally, the obtained results were analyzed by univariate and multivariate covariance analysis using SPSS software.

Results: The results of the multivariate covariance analysis for determining the effect of the group on student's adjustment was significant in the post-test and follow up $(\mathrm{P}<0.05)$. As well as the results of univariate covariance analysis to determine the effect of the group on the level of positive relationships with others in the post-test and follow up was statistically significant $(\mathrm{P}<0.05)$. Also, the findings indicated that the intervention effect on the variables in the follow up stage was invariant.

Conclusion: The results of this study indicated that the cognitive social skills training program was experimentally effective in cognitive restructuring, cognitive impairment and causal bias, as well as the enhancement of interpersonal skills in enhancing the skills of the students.

Citation: Kabiri L, Shokri O, Pourshahriar H. Effect of cognitive social skills training on positive relationships with others and adjustment of students. Advances in Cognitive Sciences. 2019;21(3):105-119. 


\title{
تأثير آموزش مهارتهاى شناختى_اجتماعى بر روابط مثبت با ديكران و سازكارى دانش آموزان
}

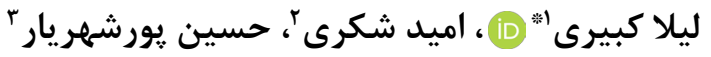

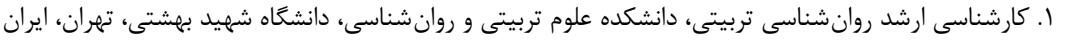

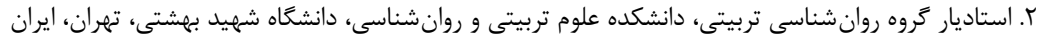

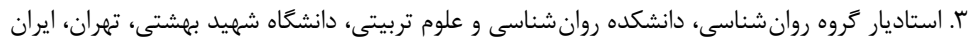

\section{حكده}

مقدمه: روانشناسان و متخصصان علوم رفتارى همواره سعى داشتهاند با توسعه برنامههاى آموزشى گوناكون، سطح سازگًارى افراد را در كروههاى سنى مختلف افزايش دهند. بر اين اساس، مرور نتايج مطالعات در حوزه شناختى_اجتماعى، نشان مى دهد كه بخش قابل ملاحظهاى از كنشورى نامناسب نوجوانان، به نقص در خزانه مهارتى آنها مربوط مىشود. بنابراين مطالعه حاضر با هدف اثربخشى آموزش مهارتهاى شناختى_اجتماعى بر روابط مثبت با ديكران و سازگًارى نوجوانان انجام شد. روش كار: در اين يروهش نيمهآزمايشى با طح بِيش آزمون_يس آزمون با گروه كنترل و همراه با پِيخيرى دو ماهه، از جامعه آمارى

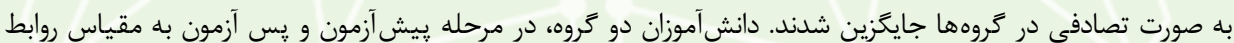
مثبت با ديخران و مقياس سازكارى، ياسخ دادند. براى دانشآموزان كروه آزمايش به مدت •ا هفته و هر هفته حدود r

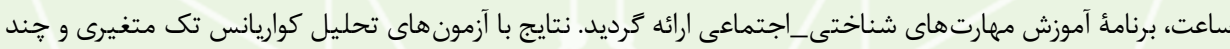
متغيرى و با استفاده از نرم افزار SPSS-18 تحليل شدند. يافته ها: نتايج تحليل كواريانس جندمتغيرى براى تعيين اثر كروه بر سازكارى دانشآموزان در مرحله پِ آزمون و بِيخيرى معنادار بود (ه•/P> Pمهنين، نتايج تحليل كواريانس تك متغيرى براى تعيين اثر گروه بر ميزان روابط

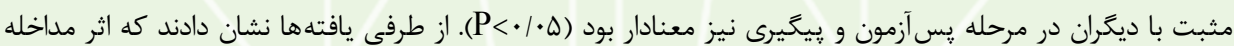

$$
\text { بر متغيرها در مرحله بِيخيرى ثابت بوده است. }
$$

نتيجه كَيرى: نتايج نشان داد كه برنامه آموزش مهارتهاى شناختى_اجتماعى از طريق بازسازى شناختى، اصلاح اسنادهاى علّى و تحريفهاى شناختى و همجنين يربارسازى مهارتهاى رابطه بينفردى در تقويت خزانهُ مهارتى فراگيران به طور تجربى مؤثر بود.

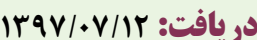

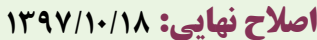

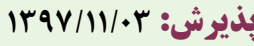
وازهماى كليدى مهارت هاى رابطه بين فردى سازگًارى مهارتهاى شناختى_اجتماعى سلى

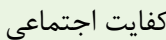

نويسنله مسئول ليلا كبيرى، كارشناسى ارشد روانشناسى

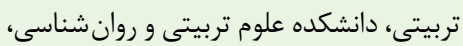
دانشگاه شهيد بهشتى، تهران، ايران

ايميل: L.kabiri.2525@gmail.com

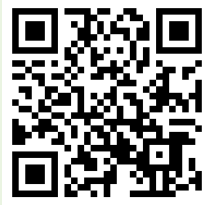

doi doi.org/10.30699/icss.21.3.105

مقلdمه

آنها به موازات فراهمسازى بستر اطلاعاتى مناسب براى رشديافتخى شناختى فراگيران، همواره در كانون توجه محققان مختلف بوده است (1) (1). بر اين اساس، نتايج برخى مطالعات نشان دادهاند كه هر گونه تلاش نظامدار با هدف كمك به يادگيرى صرف هر جه بيشتر مطالب درسى، بدون توجه كافى به نيمرخ مشخصه هاى هيجانى_اجتماعى آنها
مرور تلاشهاى تحقيقاتى روانشناسان در سال هاى اخير نشان مى دهد دامنهُ معنايى مفهوم يادگيرى در موقعيتهاى ييشرفت وسعت يافته است. بنابراين، با افزودن مولفههاى هيجانى_اجتماعى به بدنهُ معنايى تهري مفهوم يادَيرى، دغدغهُ بهبود نشان گرهاى كيفى زندگى تحصيلى فراگيران به كمك تقويت خزانه مهارتهاى هيجانى و اجتماعى در 
بهزيستى روانشناختى مثبت آدمى تلقى مىشود (1). Ryff تاكيد

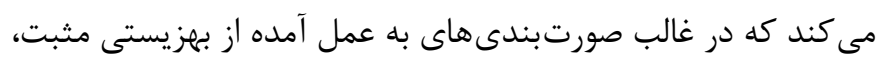

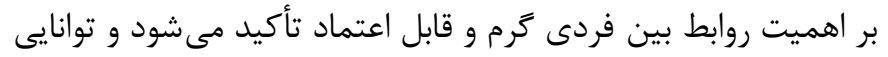
عشق ورزيدن به عنوان يك مؤلفه اصلى سلامت روانى تلقى شده است.

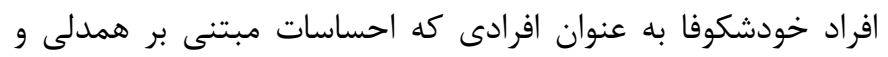

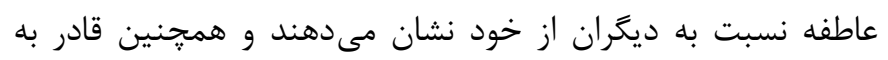

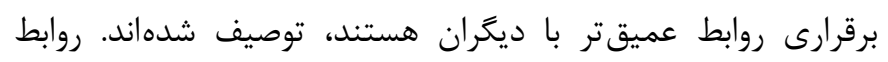

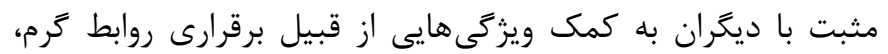
رضايتبخش و قابل اعتماد با ديكران، حساسيت نسبت به رفاه ديكران، قابليت همدلى بالا و صميميت بين فردى مشخص مى گردد (• T، آل). بر اساس شواهد نظرى و تجربى موجود، يكى از قلمروهاى مفهومى

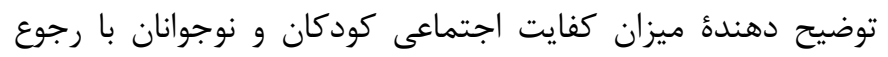

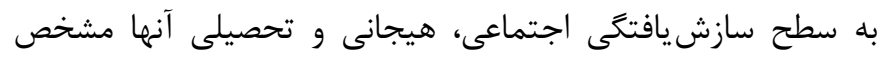

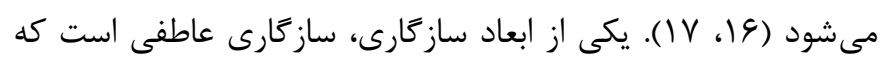

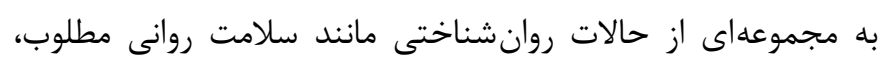

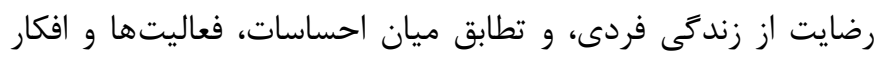
اطلاق مىشود. بر اين اساس، سازگًارى عاطفى را مى توان سازوكارى تلقى كرد كه فرد از طريق آن به ثبات عاطفى دست مى يابد. ساز كارى عاطفى نيازمند شناخت خود آكاهى از توانايىهاى خود و يذيرش كاستىهاى فردى مىباشد. افرادى كه از سازكارى عاطفى پإيينى

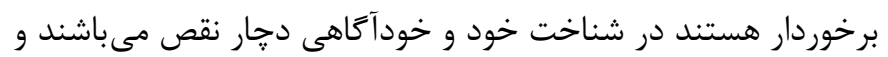

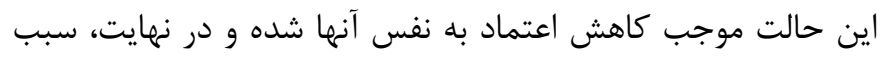

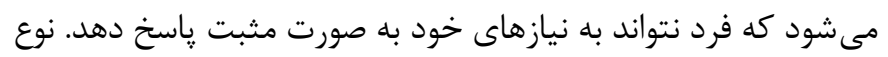

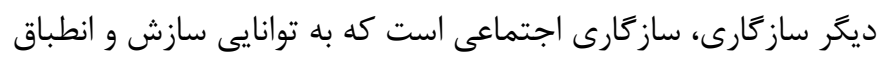

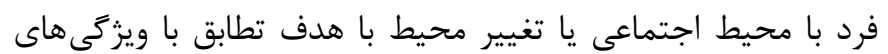
فردى اشاره دارد. بنابراين، هدف ساز كارى اجتماعى، كه از توانايى لازم

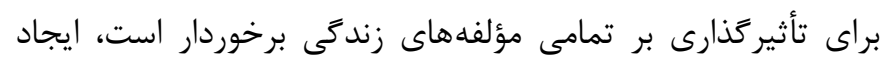

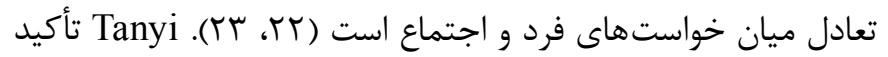
مى كند كه سازگارى تحصيلى بيانكر توانايى فرد براى كنار آمدن با تقاضاهاى تحصيلى و فعاليتهاى مدرسه و ساز كارى هيجانى فرايند

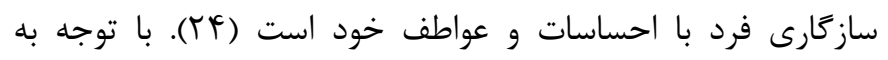

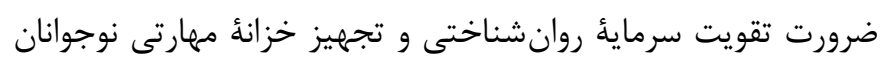

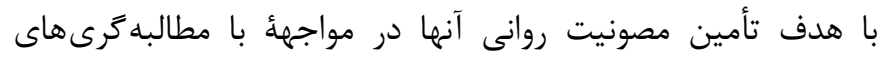
جندَانه در موقعيتهاى مختلف تحصيلى و بين فردى مدى محققان مختلف تلاش نمودند با استفاده از برنامههاى آموزشى متفاوتى مانند

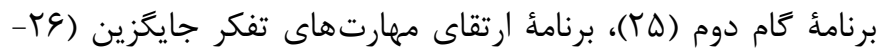

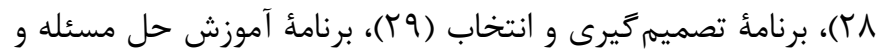

مى تواند مسير دستيابى به نشانكرهاى كمى اثربخشى زندكى تحصيلى

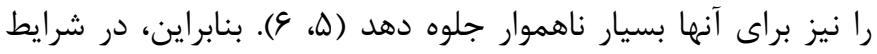

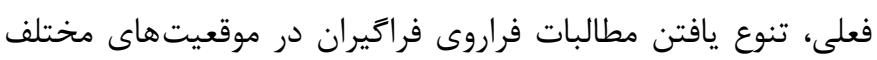

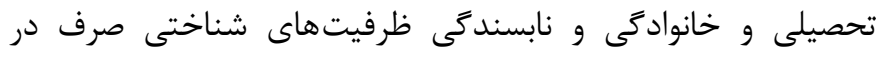

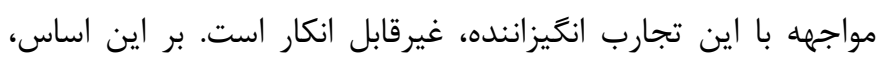

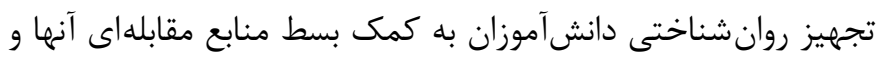

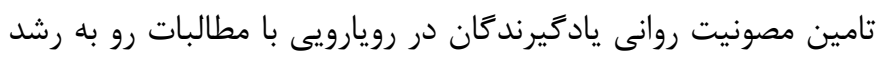

زندكى تحصيلى، بيش از بيش مورد تاكيد قرار گرفته است (V-V I I). برخى مدل هاى نظرى زيربنايى مانند نظريئ يردازش شناختى اطلاعات

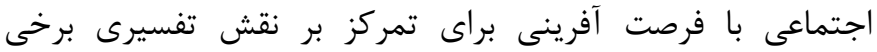

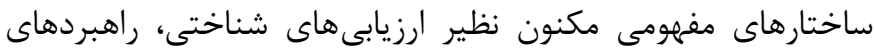

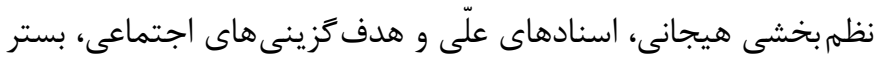

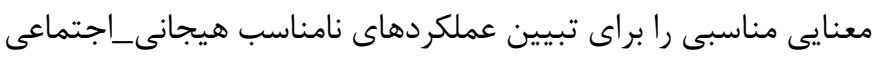

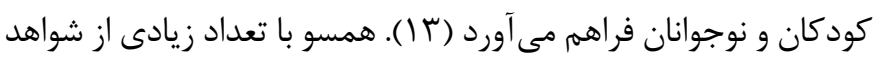
تجربى، الكوى تجديد نظر شده يردازش شناختى اطلاعات اجتماعى از

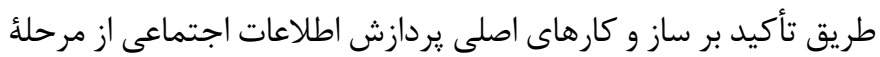

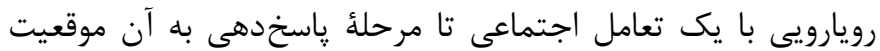
بين فردى، در درك بهينُٔ ساز گارى اجتماعى و الكَى كيفى تعاملات

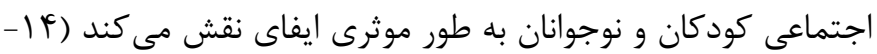

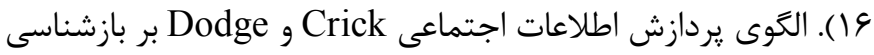

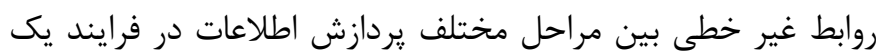

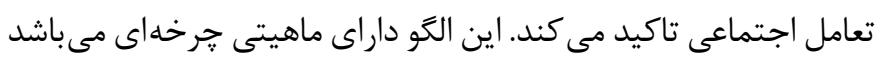

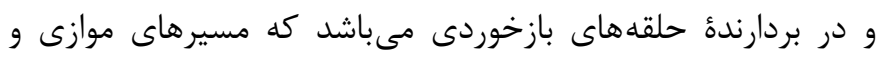

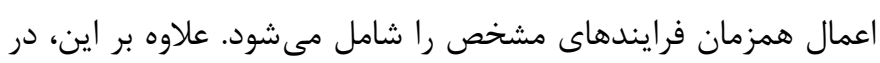

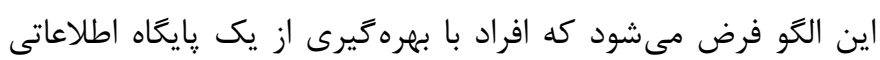
معين كه مشتمل بر دانش مبتنى بر تجارب بيشين، نقشهاى اجتماعى إنى و طرحوارههاى اجتماعى است، به درون يك موقعيت اجتماعى قدم مىنهند. اين پايخاه اطلاعاتى مشتمل بر ساختارهاى ذهنى مكنونى است كه از خاطرات تجارب بين فردى ييشين و دانش اجتماعى فرد

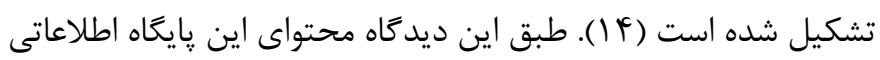

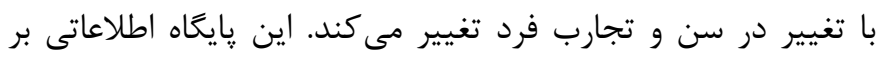

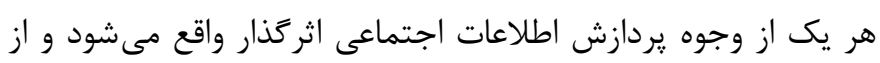

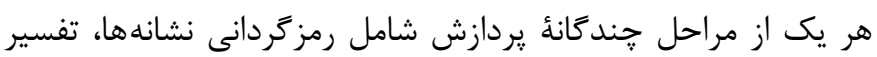

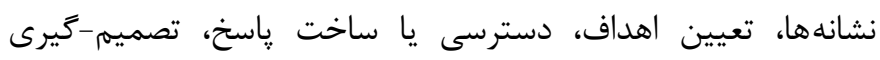

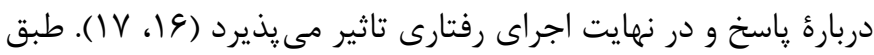

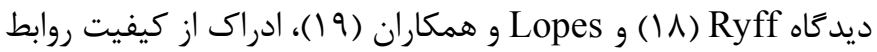

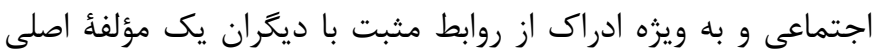


تركيبى در افزايش برخى كيفيتهاى روانشناختى در كودكان مانند

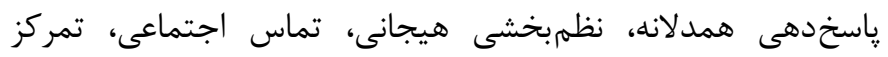

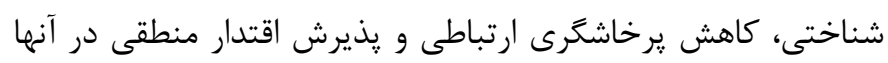

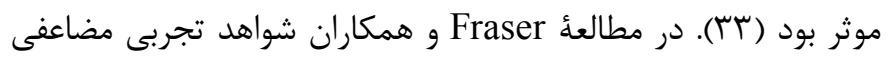

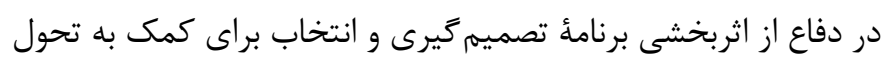

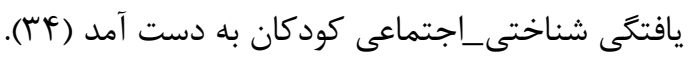

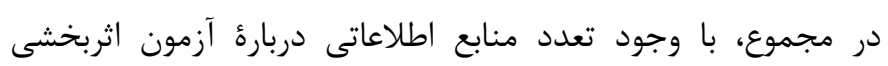

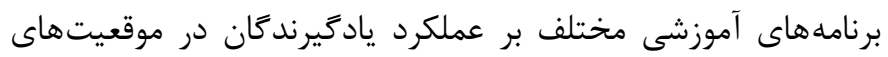
بيشرفت، در بين محققان مختلف، مرور دقيق شواهد تجربى مختلف دران

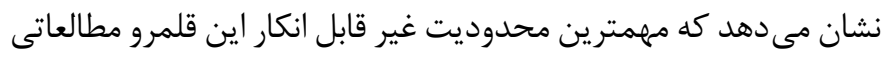

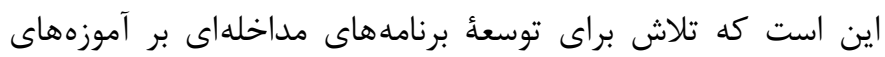

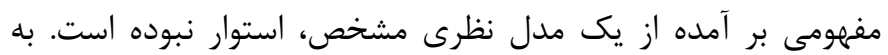

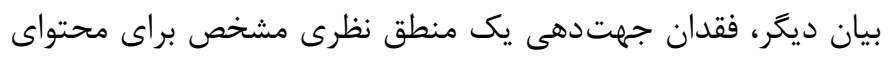

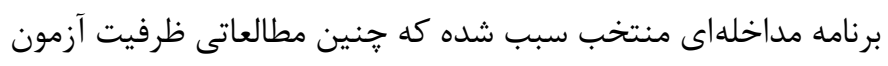

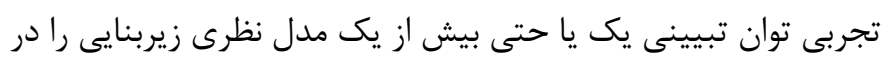

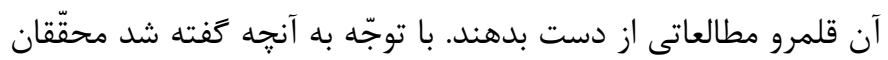

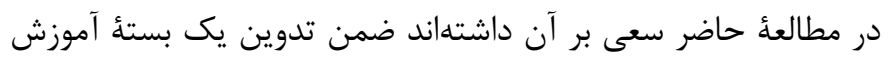

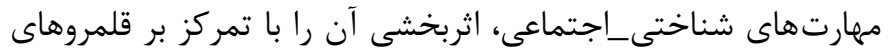

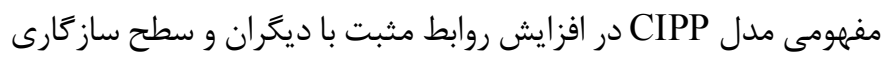
هيجانى، اجتماعى و تحصيلى آنها نيز موثر واقع شوند. بنابراين، هدف

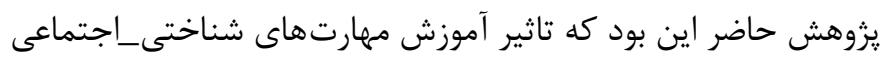

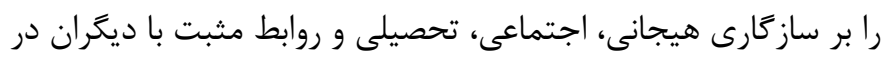

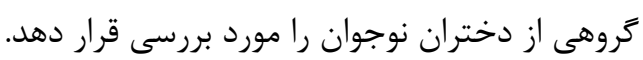

\section{روش كار}

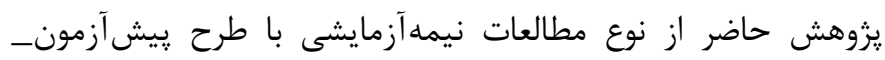

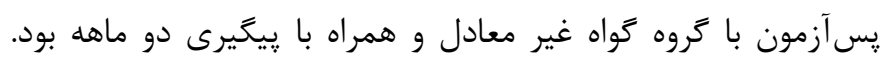

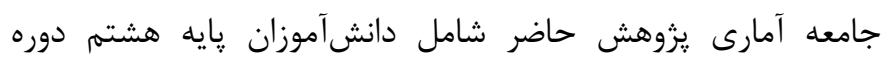

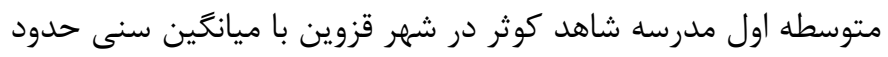

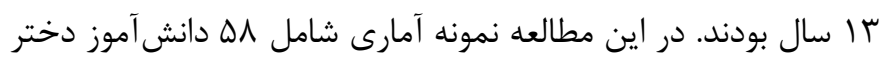

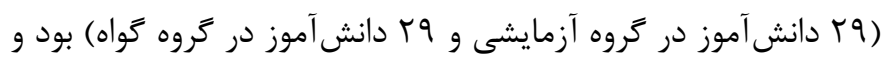

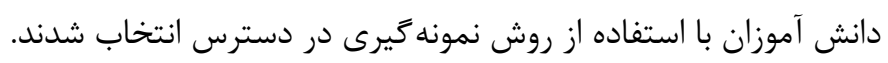

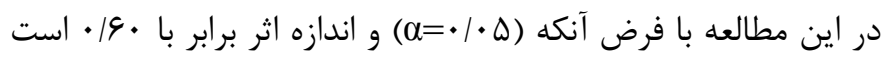

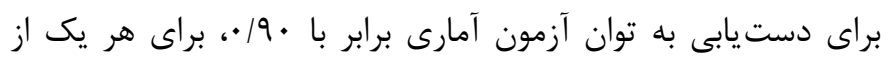

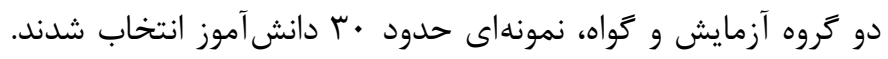

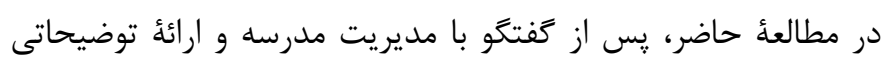

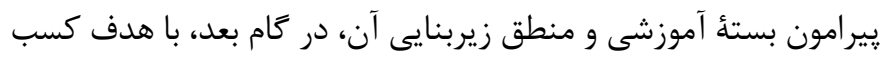

مهارت هاى اجتماعى (•r) و برنامهٔ جامع آموزش مهارتهاى بين فردى

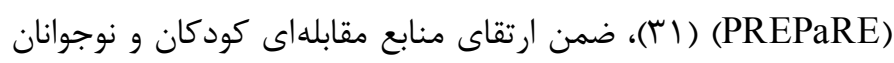

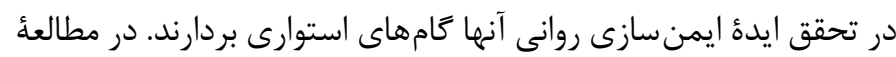

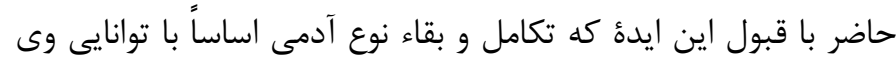

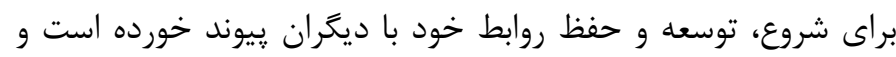

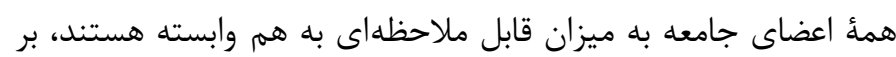

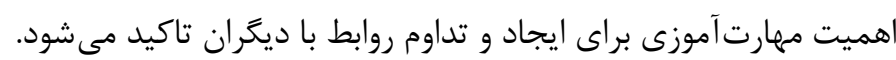

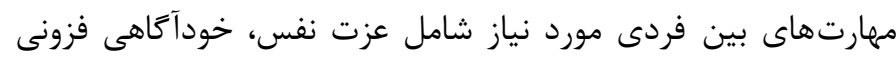
يافته، مهارتهاى تفكر منطقى، واقع گرا، منعطف، خلاق، فعالانه، مثبت

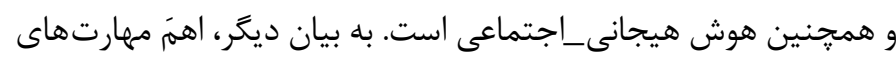

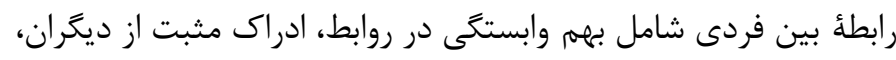

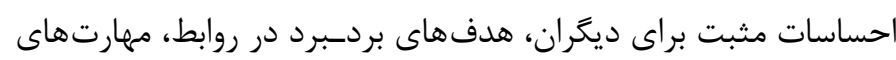

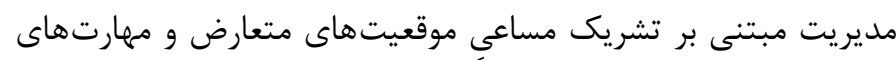
تعامل بين فردى است.

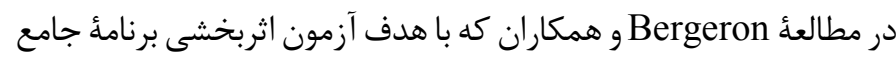

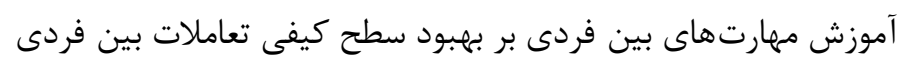

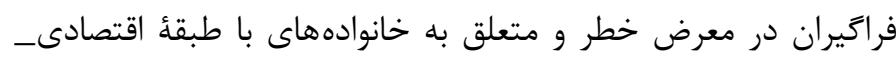

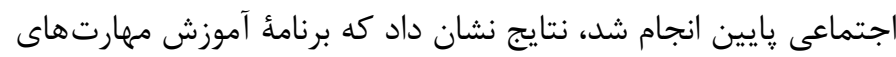

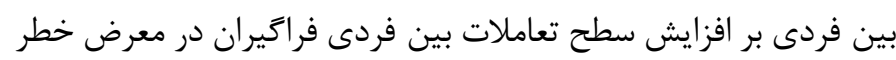

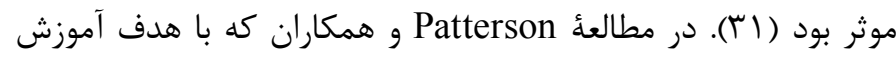

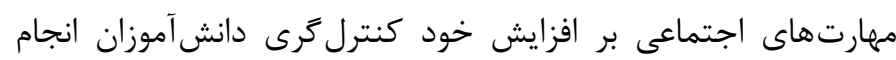

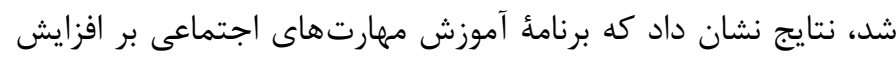

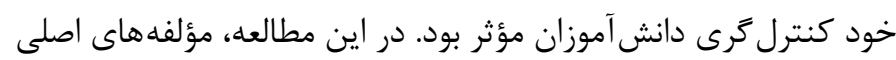

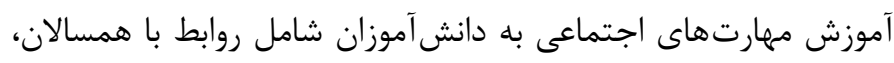

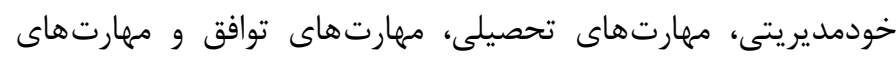

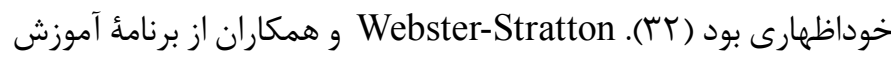

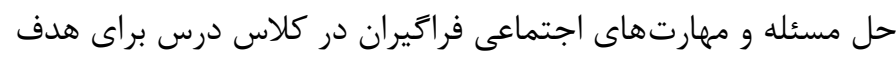
تقويت كفايت هيجانى و اجتماعى دانش آموزان استفاده كردند. نتايج

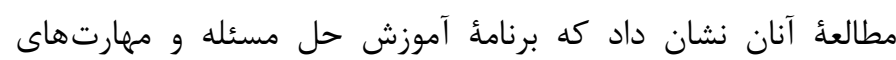

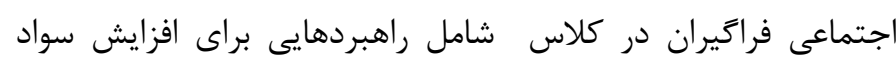

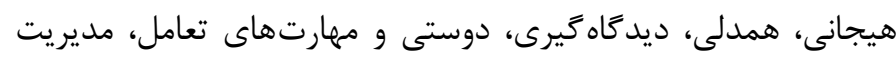

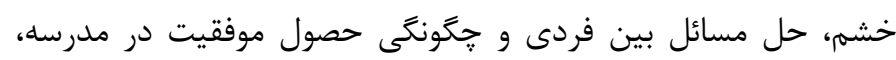

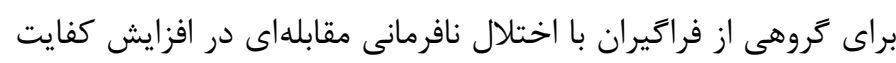

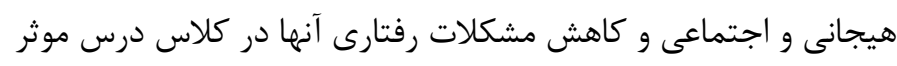

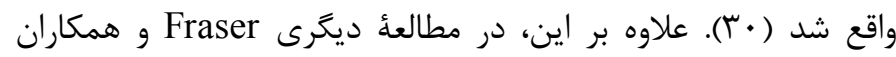

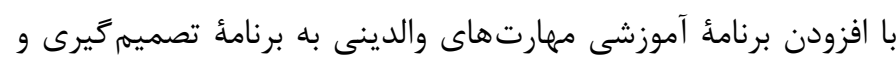
انتخاب، ضمن توسعُ برنامئ Strong family، دريافتند كه اين برنامئ 


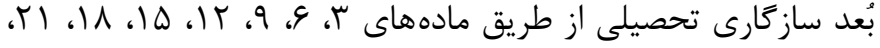

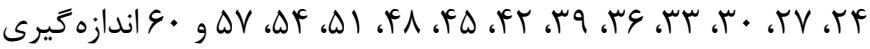
مىشود. در اين سياهه، به منظور نمرهذارى هر يك از مقياسها، به پاسخهاى مبتنى بر سازكارى نمره صفر و به باسخخهاى غيرمنطبق

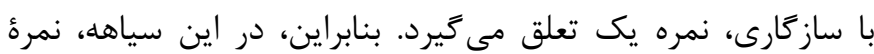

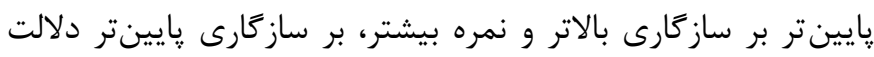

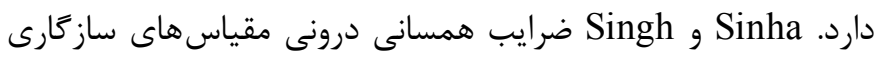

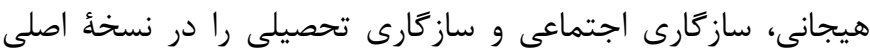

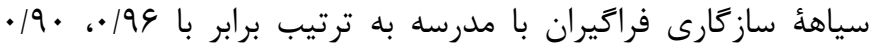

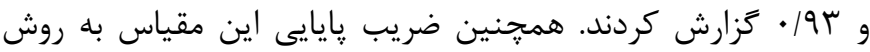

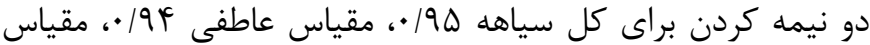

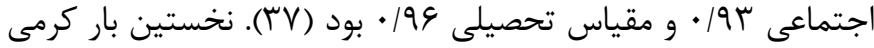

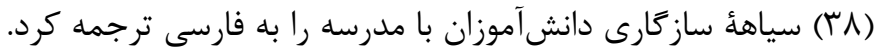
نتايج مطالعات مختلف از ويزگى هاى روايى و پايايى سياهه ساز كارى

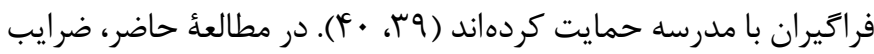
همسانى درونى ساز كارى هيجانى، اجتماعى و تحصيلى به ترتيب برابر با

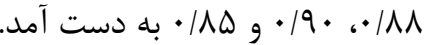
در اين مطالعه، از "برنامه غنى سازى مهارتهاى شناختى_اجتماعى" مبتنى بر مدل تجديدنظر شده Crick و Dodge (f) (1)، استفاده شد. يُ إز انتخاب دانش آموران و جايكزينى تصادفى آنها به كروههاى

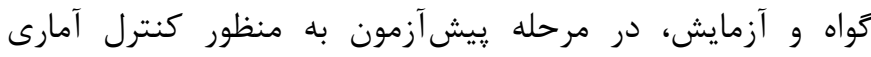

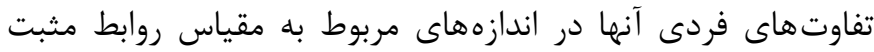

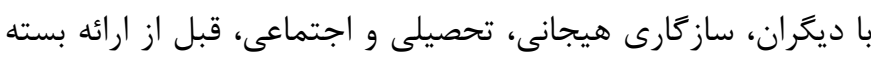

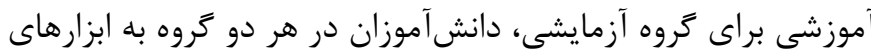

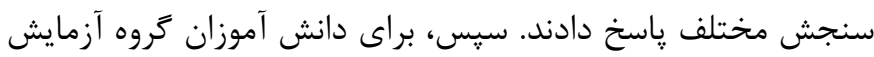

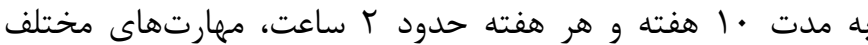
"برنامه غنى سازى مهارتهاى شناختى_اجتماعى" ارائه شد (جدول (). اين برنامه به وسيلة يكى از نويسندكان مقاله كه داراى كواهى رسمى تسلط بر دورههاى آموزشى مختلف مانند برنامٔ رفتار درمانى

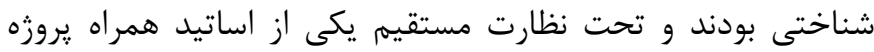

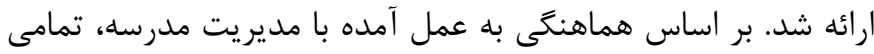

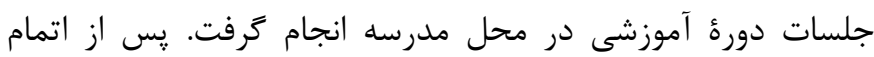

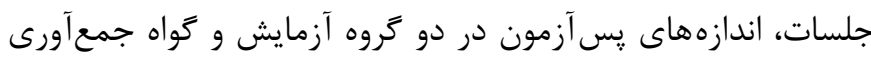

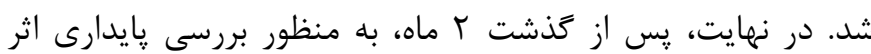

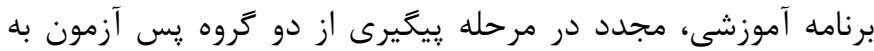

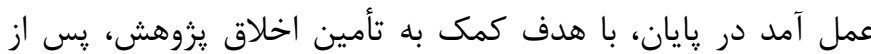
كردآورى دادها هر مرحله بِيخيرى، محتواى برنامه آموزشى منتخب
رضايت آكاهانهٔ والدين، از آنها تقاضا شد تا در يك جلسه رسمى براى آشنايى با بستهٔ آموزشى حاضر شوند. در پايان جلسه تمامى مادران

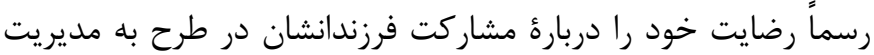
مدرسه اعلام نمودند. در اين بخش، محققان با هدف كمك به كنترل

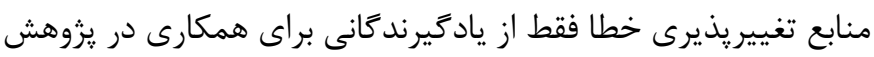
دعوت كردند كه سابقة دريافت خدمات روانشناختى و يا استفاده از داروهاى تجويز شده توسط روان يزشكان را نداشتهاند. علاوه بر اين، مقرر شد كه در صورت عدم حضور در دو جلسه آموزشى، دادههاى مشاركتكنندكان در تحليل نهايى استفاده نشود. علاوه بر اين، براى محققان عدم مشاركت فعالانه نوجوانان در انجام تكاليف ضمن آموزش و تكاليف خانگى نيز به عنوان يكى ديخر از ملاكهاى خروج انتخاب شد. در اين

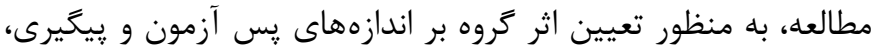

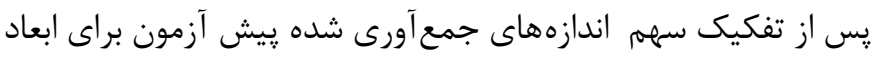

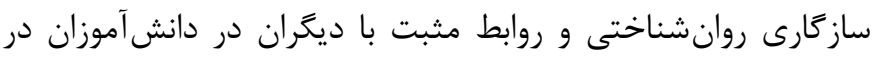

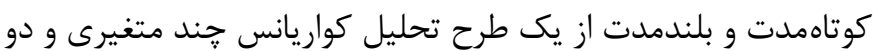
طرح تحليل كواريانس تك متغيرى استفاده شد. مقياس روابط مثبت باديكران Scale of Positive Relationships with Others) (9)، به منظور تحليل سيستميك ادراك از كيفيت روابط اجتماعى در نوجوانان، از مقياس روابط مثبت با ديخران در الكَى نظرى بهزيستى

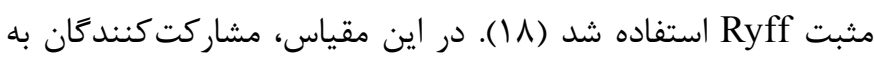

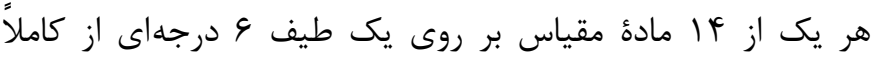

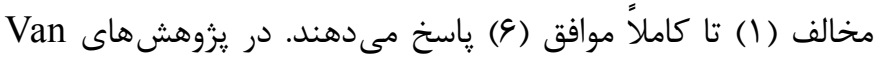
Dierendonck

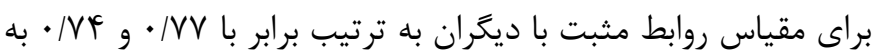
دست آمد. در مطالعة حاضر، ضريب همسانى درونى روابط مثبت باس

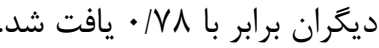

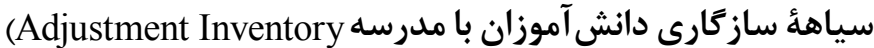
Singh و با هدف تمييز دانشآموزان كروه Sinha :for School Students)

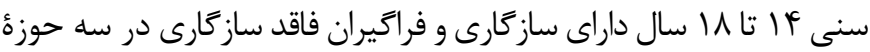

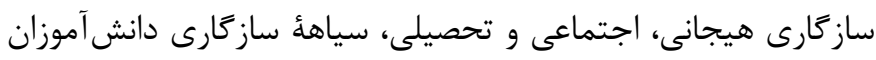

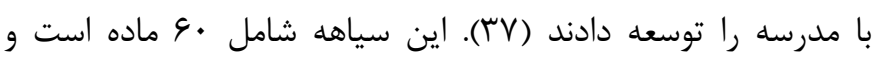

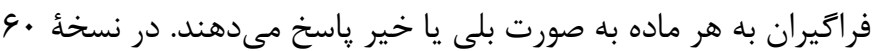

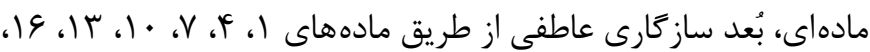
19 1 זr،

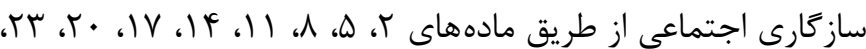

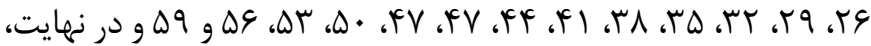


آزمايشى، بر حسب ضوابط و ملاكهاى از قبل يبشبينى شده، در ده جلسه به دانشآموزان گروه گواه كه در فهرست انتظار به سر محققان با ريزش مشاركت كنندًان روبرو نشدند. مىبردند، نيز ارائه شد. در اين مطالعه، براى هيج يك از كروههاى

جدول ا. فهرست محتوايى برنامه آموزش مهارتهاى شناختى_اجتماعى به تفكيك هدفها و فعاليتها

\section{فعاليت ها}

آشنايى اعضا با يكديكر و مدرس و تشريح برنامه آموزش اجراى پيشآزمون، مرور مجمل زيربناى نظرى برنامه آموزش مهارتهاى

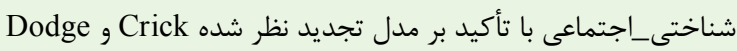

مهارتهاى شناختى_اجتماعى

آموزش الگَى رابطه بين حالات هيجانى متعاقب رويارويى با ارائه جندين سناريوى دربردارنده يك اتفاق ناراحت كننده، پيامدهاى مواجهه با اين رخدادهاى منفى با نظام باورهاى فرد بر اساس مدل اليس و رويدادها و باورهاى زيربنايى اين קيامدها. همجنين، تعريف مفهوم اسناد خوشبينى

در برابر بدبينى، تبيين رويدادها بر اساس الگوى اليس (مدل تفكر ABCDE). مشاركتكنندكان به كمك جهار اصل: 1- گردآورى شواهد r- مطرحكردن تفسيرهاى جايكزين بـ- اجتناب از فاجعه يندارى f أ- تدوين نقشهى حمله، فن مجادله با افكار منفى را مى آموزند.

غنىسازى روابط بينفردى با تأكيد بر دو عنصر مفهومى 》انسجامه يا پِيوند هيجانى دو فرد با يكديگر و "اسازش يافتكى يا تطبيق يافتكى" يا توانايى افراد براى تغيير در پِاسخ خود نسبت به ديكرى براى دستيابى به تعادل. غنى سازى روابط بينفردى با تأكيد بر لادراك برابرنكرانه《، "بازشناسى نيرومندها《، "يذيرش و احترام" و درنهايت "تصديق تفاوتهاش. غنى سازى روابط بين فردى نيازمند آن است كه احساسات افراد نسبت به ديكران به كمك ويرَّى هايى مانند "كرم بودن"، (انسانى بودن" و "همدلى" مشخص شود. غنىسازى روابط بينفردى با تأكيد بر تمايز در تبعات انتخاب يكى از سه كزينهُ هدف برد_باخت، هدف باخت_برد و در نهايت هدف بردـبرد. ارزيابى الكوى اسنادى افراد در مواجهه با رويدادهاى ناخوشايند

آموزش مهارت دستيابى ادراكات مثبت نسبت به ديغران آموزش انتخاب اهداف برد_برد در روابط
جلسه جلسه اول

جلسه دوم

جلسه جههارم جلسه ينجم

جلسه ششم آموزش مهارت دست يابى احساسات مثبت نسبت به ديخران جلسه هفتم آموزش مهارتهاى مديريت تعارض هميارانه جلسه هشتم حل موقعيتهاى متعارض شامل راهبردهاى هميارانه، اجتنابى و يرخاشخرانه. براى دستيابى به حل موفقيت آميز مسائل ينج مرحله: ا- درنگ كردن و انديشيدن

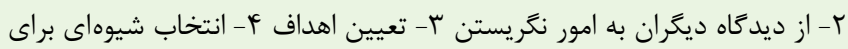
جلسه نهم آموزش مهارتهاى حل مسئله عمل پِ از تعيين موارد مثبت و منفى ه- آزمون اثربخشى راه حل انتخابى. آموزش جرأتورزى با تأكيد بر 1- توصيف وقايع عينى ؟- بيان احساسات بـخواستار تغيير اختصاصى و مختصر †- بررسى تأثير تغيير بر نحوه احساس و آموزش مذاكره با تأكيد بر ا- مشخص سازى يك خواست منطقى و دستنيافتنى آموزش مهارتهاى تعامل بين فردى (جرأتورزى و مذاكره) جلسه دهم r- به زبان آوردن خواست منطقى بـ- توجه به خواست هاى طرف مقابل F- تلاش براى رسيدن به توافق ه- تدوام مذاكره تا دستيابى به توافق. اجراى يس آزمون. 
قبل از به كارگيرى تحليل كواريانس، براى طرحهاى تحليل كواريانس

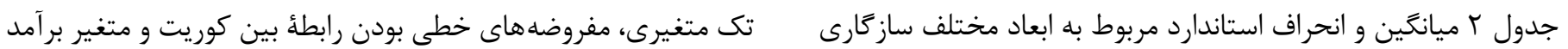

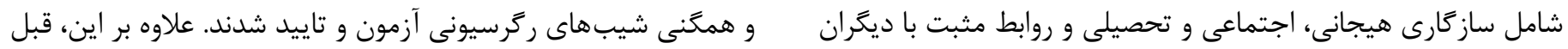

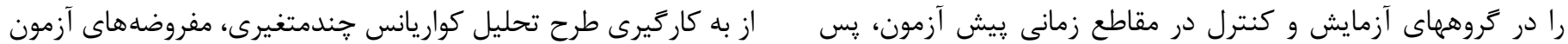

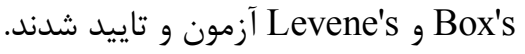

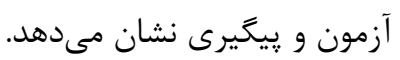

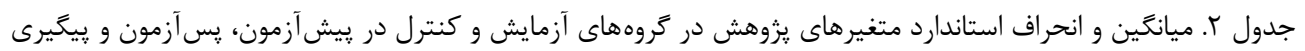

\begin{tabular}{|c|c|c|c|}
\hline ميانكين土 انحراف استاندارد & 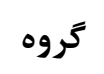 & مرحله - & متغير \\
\hline$r / T G \pm G / T r$ & آزمايش & \multirow{2}{*}{ بيش آزمون } & \multirow{6}{*}{ سازگًارى هيجانى } \\
\hline 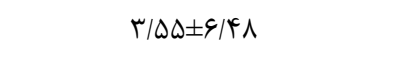 & كنترل & & \\
\hline$r / \mathcal{F T} \pm \Delta / 1$. & آزمايش & \multirow{2}{*}{ يس آزمون } & \\
\hline 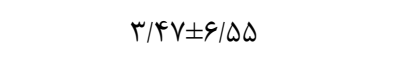 & كنترل & & \\
\hline 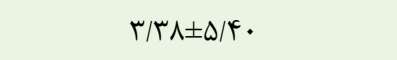 & آزمايش & \multirow{2}{*}{ بيخيرى } & \\
\hline$r / \mu F \pm q / \lambda$. & كنترل & & \\
\hline$r / \Gamma Y \pm V / F \Lambda$ & آزمايش & \multirow{2}{*}{ بيش آزمون } & \multirow{6}{*}{ سازَارى اجتماعى } \\
\hline$\Gamma / \Gamma / \pm V / \Delta \Lambda$ & كنترل & & \\
\hline$r / 9 \Delta \pm 9 / \Psi \wedge$ & آزمايش & \multirow{2}{*}{ 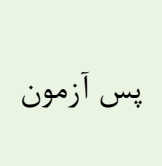 } & \\
\hline$\Gamma / \Delta \Lambda \pm V / \& V$ & كنترل & & \\
\hline$\Gamma / \varphi \mid \pm \Delta / 9 \varphi$ & آزمايش & \multirow{2}{*}{ ي يَغيرى } & \\
\hline$r / \Delta V \pm \varepsilon / \wedge q$ & كنترل & & \\
\hline$r / \Delta q \pm V / r)$ & آزمايش & \multirow{2}{*}{ بِيش آزمون } & \multirow{6}{*}{ سازَارى تحصيلى } \\
\hline$r / \uparrow \Delta \pm V / \Delta \varphi$ & كنترل & & \\
\hline$r / \mu r \pm g / r$. & آزمايش & \multirow{2}{*}{ يس آزمون } & \\
\hline$r / r r \pm V / \mathcal{R}$. & كنترل & & \\
\hline$r / q \vee \pm \Delta / \xi \Lambda$ & آزمايش & \multirow{2}{*}{ بيخيرى } & \\
\hline$r / \Delta \mid \pm V / F F$ & كنترل & & \\
\hline
\end{tabular}




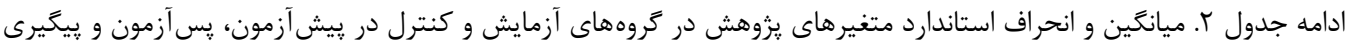

\begin{tabular}{|c|c|c|c|}
\hline ميانگيند انحراف استاندارد & تروه & مرحله & متغير \\
\hline$V|\xi| \pm r \cdot|r|$ & آزمايش & \multirow{2}{*}{ 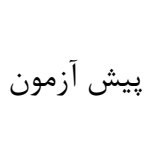 } & \multirow{6}{*}{ نمره كلى سازگارى } \\
\hline$V / \Delta \Delta \pm r \cdot / \Delta \varphi$ & كنترل & & \\
\hline$V / r \mu \pm I V / V q$ & آزمايش & \multirow{2}{*}{ 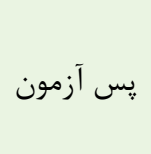 } & \\
\hline$V /{ }^{\epsilon} \Delta \pm r \mid / r$. & كنترل & & \\
\hline$V / \Delta \cdot \pm \mid \varepsilon / \Delta T$ & آزمايش & \multirow{2}{*}{ ِيخيرى } & \\
\hline$V(\Delta) \pm r \cdot 1 \Delta q$ & كنترل & & \\
\hline$V / \Delta q \pm \Delta F / T)$ & آزمايش & \multirow{2}{*}{ بيش آزمون } & \multirow{6}{*}{ روابط مثبت با ديكران } \\
\hline$V / \mathcal{F} \Delta \pm \Delta F / \Delta \&$ & كنترل & & \\
\hline$\vee / / 9 \pm \Delta ९ / \& 9$ & 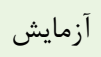 & \multirow{2}{*}{ 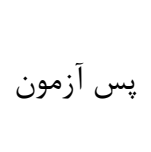 } & \\
\hline$\varepsilon / q \psi \pm \Delta F / r \mid$ & كنترل & & \\
\hline$V / \mathcal{A} \Psi \pm \Delta Q / I V$ & آزمايش & \multirow{2}{*}{ پيخيرى } & \\
\hline$V / \& V \pm \Delta r / \mathcal{F} \Psi$ & كنترل & & \\
\hline
\end{tabular}

آزمون اثر نتايج مربوط به آزمون Levene's براى نمره كلى سازگارى روانشناختى دختران در زسآزمون [F( ييخيرى [F/ واريانس هاى خطا در هر دو مقطع زمانى برقرار بود. علاوه بر اين، نتايج مربوط به آزمون Levene's در يس آزمون اول براى هر يك از ابعاد

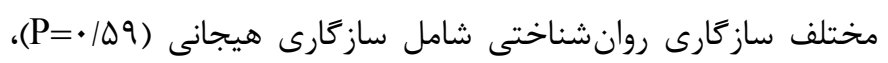

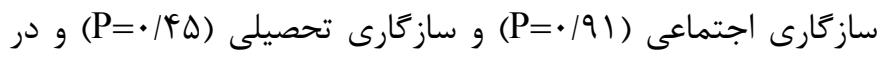
ييگيرى براى هر يك از ابعاد مختلف سازگًاى روانشناختى شامل سازگًارى هيجانى (Pr تحصيلى (r/F=• نشان داد كه مفروضأ همخنى واريانسهاى خطا بر قرار است. همجنين، نتايج آزمون Levene's براى تعيين همخنى ماتريسهاى كواريانس نشان داد كه مفروضءٔ همگنى ماتريس هاى

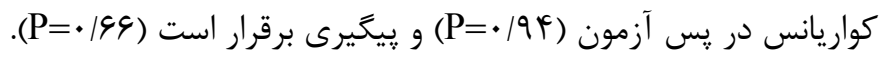

در اين بخش، ابتدا مفروضة همگنى شيبهاى رگرسيونى با هدف آزمون تاثير عامل گروه بر سازگارى كلى يس از تفكيك اندازه هاى ييش آزمون از اثرات خطا، محاسبه شد. نتايج مربوط به عدم معنادارى اثر تعاملى عامل گروهو و پيش آزمون در توضيح يراكندگى نمرات متغير سازگًارى كلى، شواهدى تجربى در دفاع از مفروضأ همكنى شيبهاى ركرسيونى در زيش آزمون [F(l و [ فراهم آورد. همجنين، نتايج مربوط به عدم معنادارى اثر تعاملى عامل گروه و ييش آزمون در توضيح يراكندگى نمرات متغير روابط مثبت با ديگران، شواهدى تجربى در دفاع از مفروضهُ همگَنى شيبهاى رگرسيونى در بيش آزمون

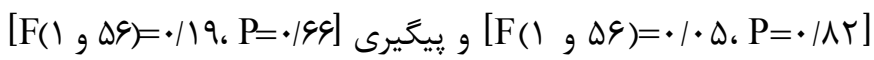
فراهم آورد. نتايج مربوط به همخنى شيبهاى رگرسيونى به عنوان يكى از مفروضههاى روش آمارى تحليل كواريانس جند متغيرى با هدف 


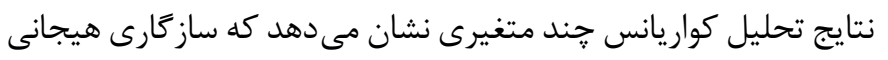

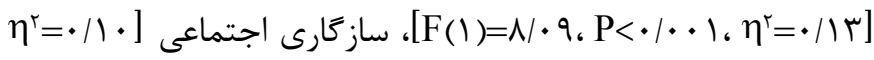

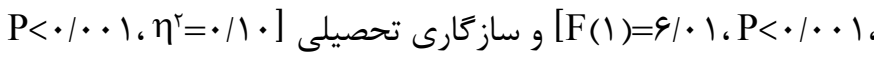

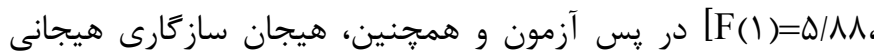

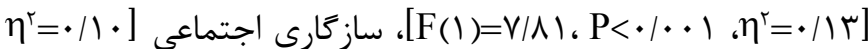

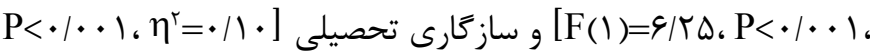

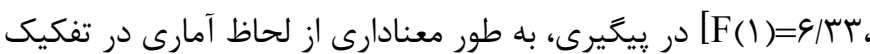
سطوح متغير مستقل مؤثر بودهاند (جدول ؟). در بخش يايانى، نتايج تحليل كواريانس تك متغيرى براى تعيين اثر عامل

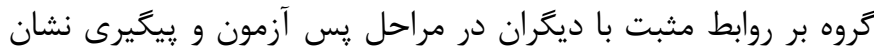

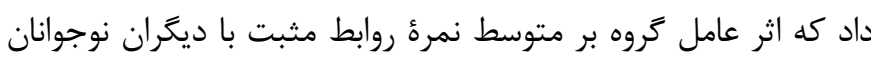

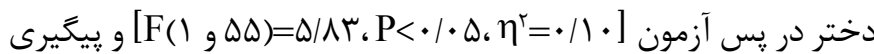
] [F( از لحاظ آمارى معنادار بود.
در نهايت، نتايج مربوط به آزمون Levene's براى نمرء كلى روابط مثبت

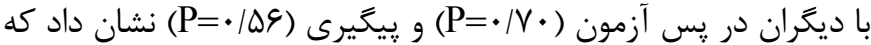

مفروضأ همكنى واريانس هاى خطا در هر دو مقطع زمانى برقرار بود. در بخش اول، نتايج تحليل كواريانس تك متغيرى براى تعيين اثر عامل گروه بر نمرء كلى سازكًارى روانشناختى دختران در مر احل يس آزمون و پِيخيرى نشان داد كه اثر عامل كروه بر متوسط نمرء كلى سازكارى روانشناختى

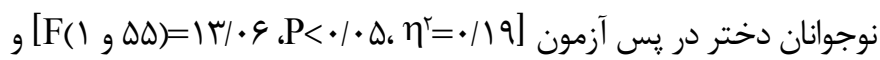

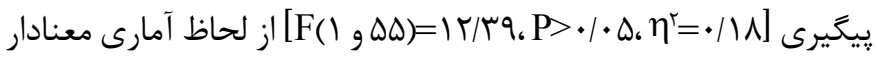
بود. در بخش دوم، نتايج تحليل كواريانس جند متغيرى براى تعيين

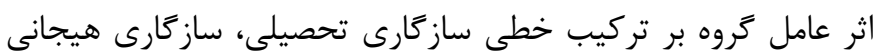

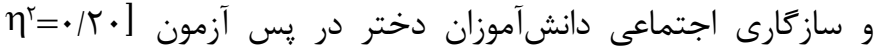

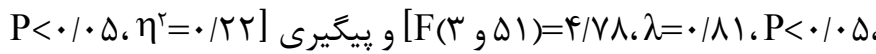
( إز لحاظ آمارى معنادار بود. در ادامه،

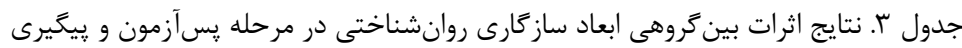

\begin{tabular}{|c|c|c|c|c|}
\hline$\eta^{r}$ & $\mathbf{P}$ & $F(d f)$ & متغير & مرحله \\
\hline.$/ 14$ & $* \cdot 1 \cdot 1$ & $N / \cdot 9(1)$ & ساز كارى هيجانى & \multirow{3}{*}{ يس آزمون } \\
\hline$\cdot 11$ & $* \cdot / \cdot 1$ & $91 \cdot 1(1)$ & سازكارى اجتماعى & \\
\hline$\cdot 11$ & $* \cdot / \cdot 1$ & $\Delta / \wedge \Lambda(1)$ & سازكارى تحصيلى & \\
\hline 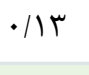 & $* \cdot 1 \cdot 1$ & $V|A|(1)$ & سازگارى هيجانى & \multirow{3}{*}{ بيخيرى } \\
\hline .111 & $* \cdot / \cdot 1$ & g/Ta (1) & سازكارى اجتماعى & \\
\hline .111 & $* \cdot 1 \cdot 1$ & G/Tr (1) & سازكًارى تحصيلى & \\
\hline
\end{tabular}

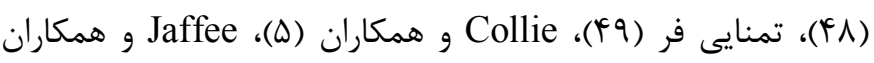

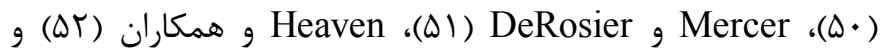
Buhs مختلف با هدف تعميق منابع مقابلهاى دانشآموزان و كمك به تحقق آنقائ مصونيت روانى در آنها به طور تجربى حمايت كرد. طبق ديدگاه Li و

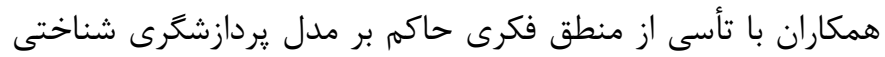

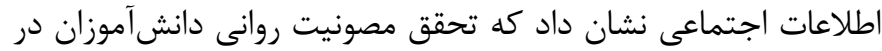
مواجهه با مطالبه كرىهاى موقعيتهاى متعارض بين فردى، نيازمند

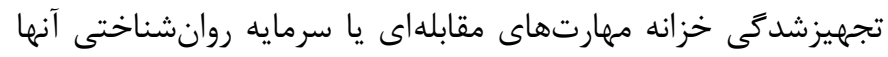

مطالعه حاضر با هدف تعيين اثربخشى برنامه آموزش مهارتهاى

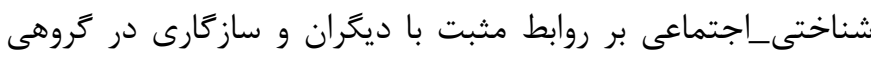

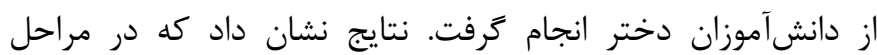

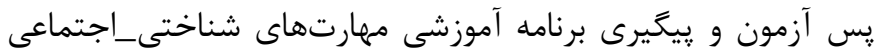
در افزايش كيفيت روابط بين فردى و نيز ارتقاء سطح سازگارى دانشآموزان دختر مؤثر بود. نتايج مطالعه حاضر همسو با يافته هاى Lemerise Arsenio Ghalifa

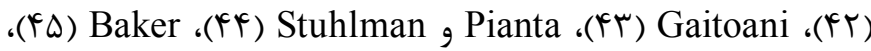
Lent 
خودگويى هاى مثبت. با توجه به انكارنايذيرى كاستىهاى انخيزشىـهيجانى متعاقب خودَّيىهاى منفى در رويارويى با موقعيتهاى باى بهاي متعارض، شناسايى و كاهش خودگويى منفى نيز در تصريح ظرفيت تفسيرى بسته منتخب با هدف كمك به تجهيز سرمايه روانشناختى

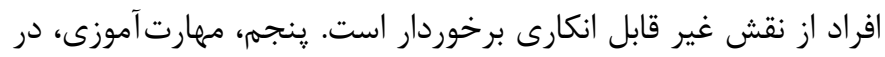

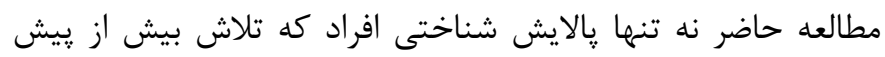

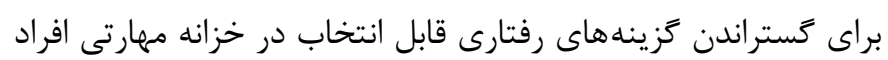
در مواجهه با موقعيتهاى انكَيزانده مانند آموزش فن مذاكره، آموزش مهارت حل مسئله اجتماعى، آموزش مهارت جرأت-ورزى و همجنين مانين آموزش مهارت حل هميارانه موقعيتهاى متعارض نيز در شناساندن توان تبيينى برنامه منتخب از نقش غير قابل انكارى برخوردار است.

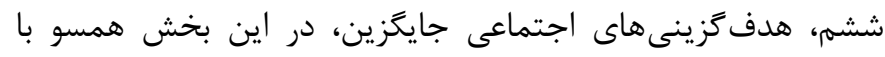

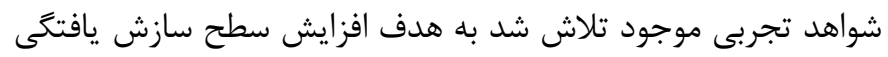

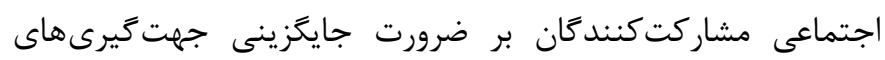

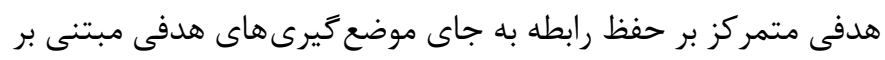

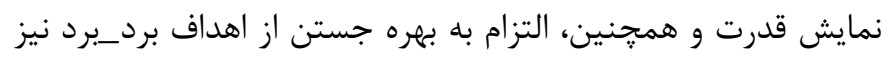
بخشى از ظرفيت بسته آموزشى را در توانمندسازى شناختى_اجتماعى مشاركت كنند كان به تصوير مى كشد (ه) (ه). نتايج مطالعة Dincyurek و Civelek نشان مى دهد كه در فرايند آموزش مهارتهاى شناختى_اجتماعى، تلاش براى تاكيد بر مختصات

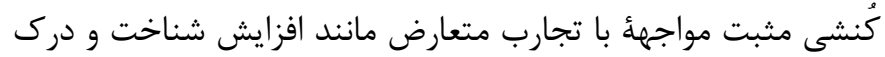

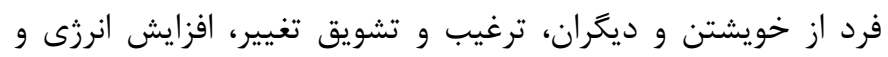

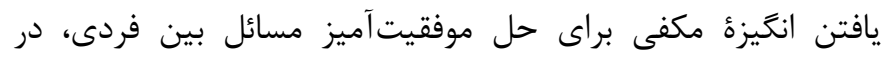

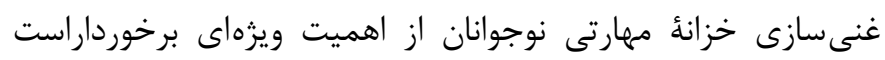

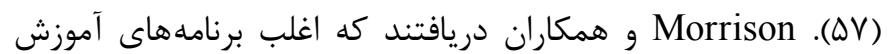
مهارتهاى رابطؤ بين فردى مانند برنامهٔ كمى به افزايش صلح،

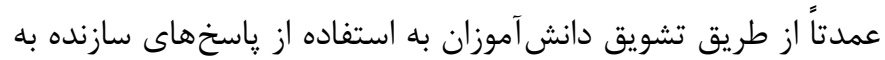
تعارضات بين فردى و نهادينه كردن رويؤ مساله مدارانه در آنها نسبت به تجارب متعارض بين فردى در تقويت ذخاير مهارتى نوجوانان موثر

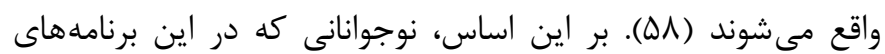

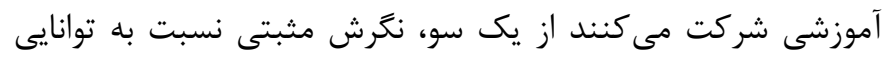

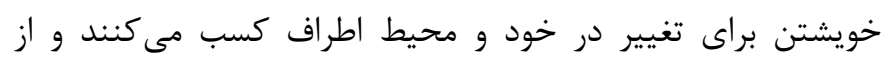

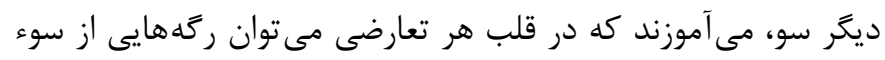
تفاهمها و ادراكات، خواستهها و نيازهاى متفاوت را جستجو كرد؛ بنابراين، تعارض به مثابؤ فرصتى براى كمك به رشد فردى ارزيابى

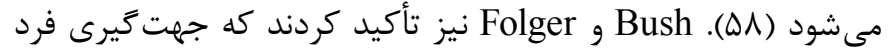
نسبت به تعارض بر جگَونكى مديريت تجارب متعارض و نتايج مرتبط بر
است (DF). به بيان ديكر، نتايج مطالعه حاضر نشان مىدهد فقر در ذخاير مربوط به منابع مقابلهاى فراگيران، كه اساساً از طريق سلطه گرى

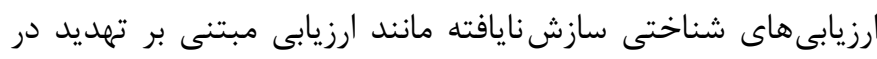

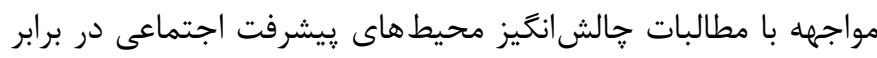
ارزيابىهاى جالشى، تفاسير شناختى خود ناتوان ساز در مقابلِ تفاسير

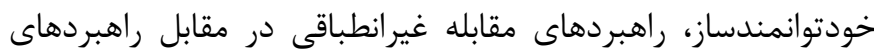

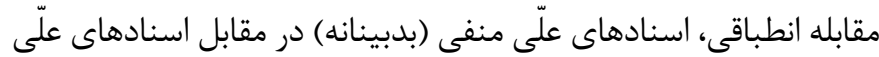

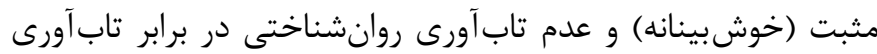
روانشناختى مشخص مىشود. ضمن محدود كردن الكوى ڤֶاسخ كيفيتمدارانه به مطالبه گرىهاى كمى، در كاهش سطح سازگًارى نوجوانان مؤثر واقع مىشوند (هD). بنابراين، همسو با ايده زيربنايى مدل يردازشكَى شناختى اطلاعات اجتماعى، گَستره معنايى مفهوم

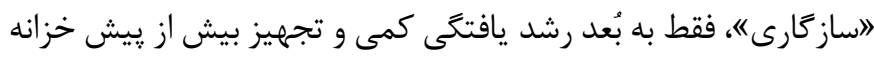

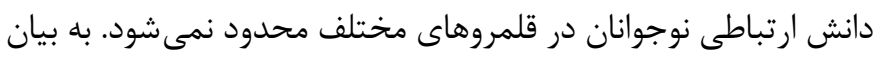
ديخر، ضرورت انديشيدن به ابعاد غير كمى تحقق سازكارى در بافت

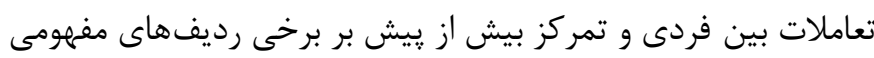
مانند اتقويت هيجانات مثبت"، "يربارسازى يا غنى سازى ممارتهاى تعاملات بينفردى" و "اتعميق خزانه منابع مقابلهاى" زمينه وسعت يافتخى معنايى مفهوم ساز كارى را سبب شده است. علاوه بر اين، با توجه به اين كه محتواى منتخب براى توسعه بسته

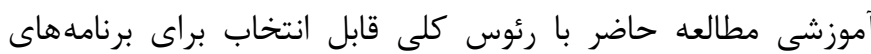
آموزش مقابله كارآمد با مطالبات انخيزاننده فراروى تناسب و تطبيق

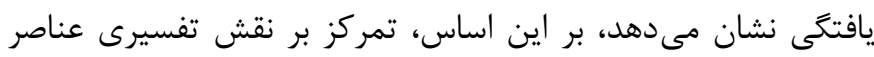

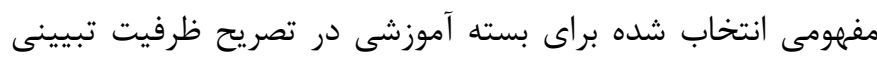

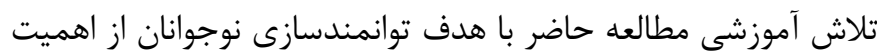

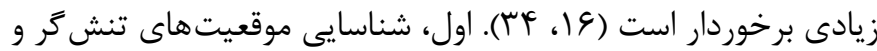
به دنبال آن واكنش هاى جسمانى، هيجانى و رفتارى متعاقب رويارويى افراد به جنين شرايطى (در بافت پاسخ به مطالبات متعاقب مواجهه با

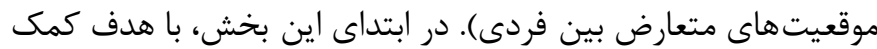
به فهم تفاوت هاى فردى در پاسخ هاى احتمالى به موقعيت هاى متعارض،

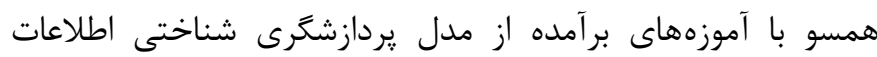

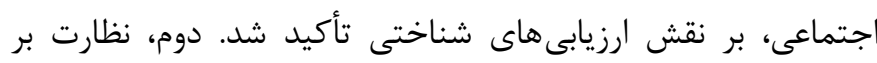

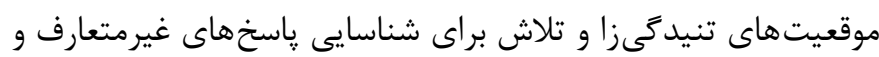

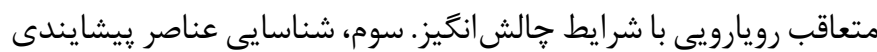
شكلدهنده و زمينهساز تجارب تنيدگىزا در بافت تعاملات بين فردى (براى مثال تأكيد بر نقش تفسيرى اسنادهاى ارتباطى يا سوگيرهاى

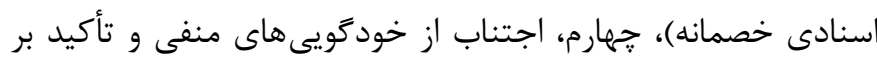


رفتارهاى مناسب، پيشگيرى از رفتارهاى مخرب، ايجاد محيطهاى اجتماعى مثبت براى همأ فراگيران و آموزش مهارتهاى حل مساله

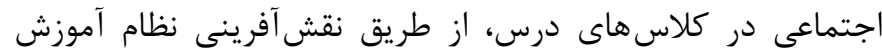
رسمى و در قلب آن معلم خواهد شد. از سوى ديكر، -Heckenlaible تو Rotto توان تفسيرى، برنامه هاى آموزش مهارتهاى اجتماعى با تمركز

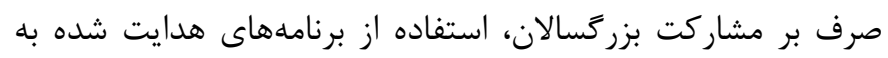

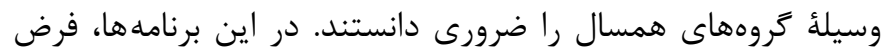
مىشود كه مشاركت همسالان و احساس مسئوليت آنها در قبال كمك به يكديكر روند يادكيرى مهارتها را تسريع مى كند. فرض هن اساسى در استفاده از اين برنامه ها اين است كه نه تنها همأ فراگيران از توانايى لازم براى حل مشكلات خود برخوردارند بلكه آنها مى توانند

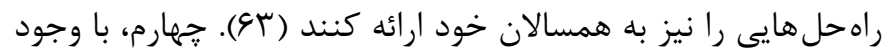

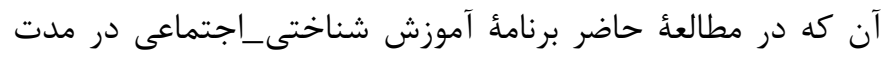

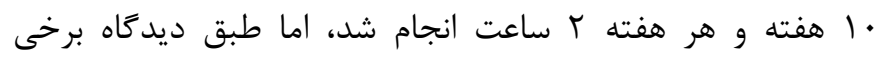

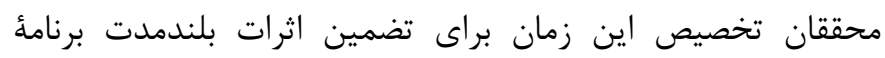

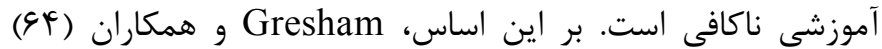
تاكيد مى كنند كه تخصيص حدود ·r ساعت زمان در طول • إهفته و هر هفته ץ ساعت براى تغيير و حفظ مهارت هاى اجتماعى جديد در

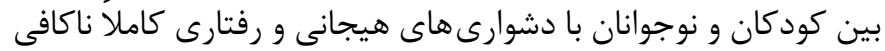
است. جنين فراگيرانى به طور حتم به زمان بسيار بيشترى براى بهبود

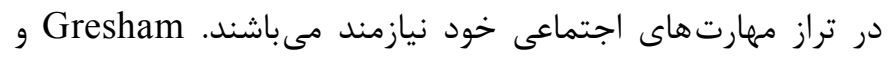

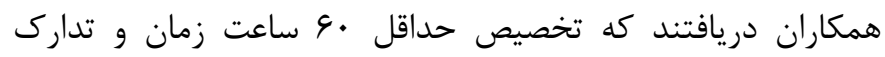

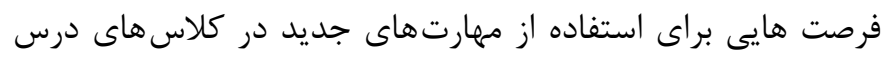

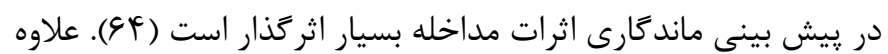

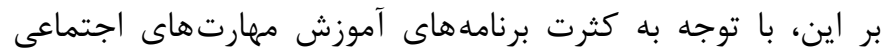
براى كودكان و نوجوانان يكى ديخر از اولويتهاى يزوهشى با اهميت إنهايت در اين قلمرو مطالعاتى با تاكيد بر مدلهاى نظرى رقيب بر مقايسٔ اثربخشى برنامة آموزش شناختى_اجتماعى مدرسه محور با برنامه

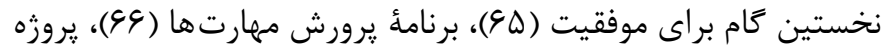

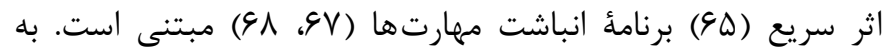

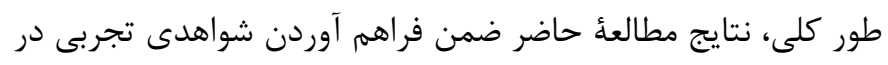

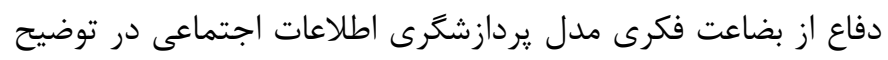
تمايز در الكوى سازشيافتخى هيجانى_اجتماعى در نوجوانان نشان

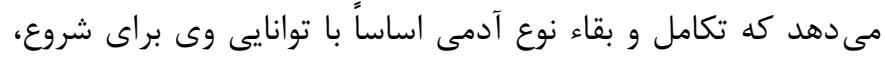
توسعه و حفظ روابط خود با ديكران يِيوند خورده است (9). همأ اعضاى جامعه به ميزان قابل ملاحظهاى به هم وابستهاند و بنابراين،
انتخابهاى رفتارى در مواجهه با موقعيتهاى متعارض موثر است. به بيان ديخر، جهت گيرى فردى نسبت به تعارض با تاثيرگذارى اقتضائات تجارب متعارض، در شكلدهى به روش ارجح جستجوى راهحل براى موقعيتهاى متعارض موثر واقع مىشود (Q9). بنابراين، عمدة تاكيد

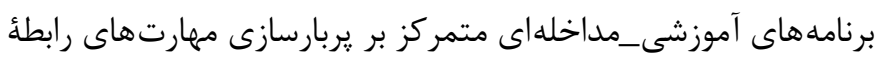

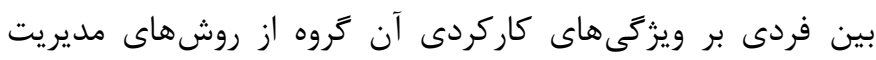

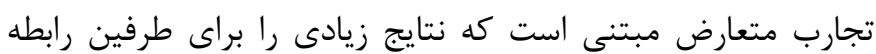

$$
\text { موجب مىشود (· (9). }
$$

با وجود مزيتهاى غير قابل انكار يزوهش حاضر در توسعه يك برنامئ آموزش مهارتهاى حل هميارانئ تعارضات بين فردى با هدف كاهش باري دشوارىهاى رفتارى_هيجانى در فراخيران، اما يزوهش حاضر خند محدوديت نيز دارد. اول، در مطالعه حاضر، عدم توجه به نقش تفسيرى متغير جمعيتشناختى جنس در فرايند آزمون اثربخشى بسته

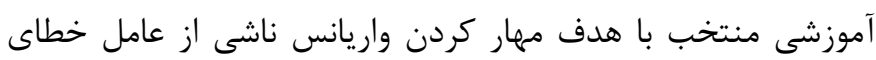

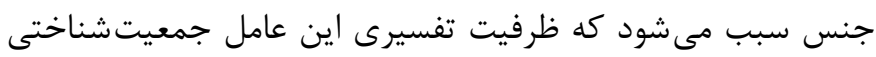
در بافت مطالعاتى تغذيه خزانه مهارتى دانشآموزان از نظر دور افتد؛ بنابراين، توصيه مى شود كه در مطالعات بعدى، تغييريذيرى منتسب به اين عامل نيز در كانون توجه محققان علاقهمند به قلمرو مطالعاتى آموزش مهارتهاى شناختى_اجتماعى به دانشآموزان قرار كيرد. دوم، در مطالعه حاضر، واحدهاى آزمايشى از جامعه آمارى به طور تصادفى انتخاب نشدند؛ فرايندى كه اغلب در محدوده تلاشهاى

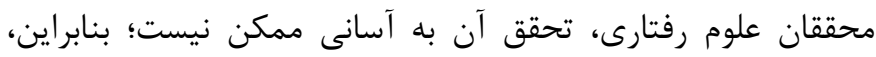
نمونه منتخب نمى تواند به طور كامل معرف جامعه زيربنايى خود باشد و البته اين مهم، تلويحاتى براى تعميميذيرى يافته هاى تحقيق

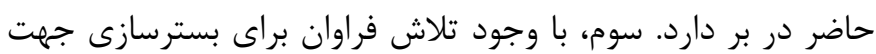

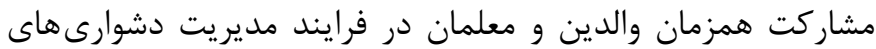
رفتارى_هيجانى فراگيران، اما همجنان يزوهش حاضر در توسعة برنامةٔ آموزشى و آزمون اثربخشى آن تعلق خاطر بيشترى به رويكرد

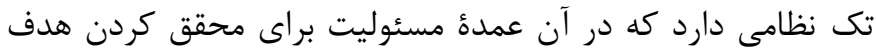
متوجه فراگيران بود. اين در حالى است كه مداخلات مبتنى بر استفاده از رويكرد نظامهاى خندكانه كه بر محيط مدرسه و خانهانه

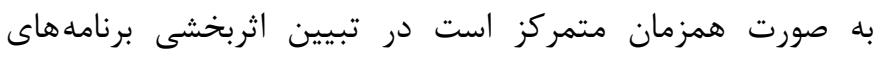

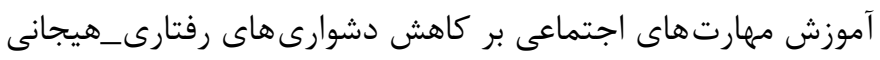
فراگيران نقش مهمى را ايفا مى كنند. محققان دريافتند كه استفاده از رويكرد نظام هاى קندكانه در تنظيم برنامه هاى مداخلهاى از طريق تقويت گسترده دغدغهمندى از مرزهاى خانه به مدرسه سبب تسهيل دسترسى به راهبردهايى مانند توجه و تشويق دانش آموزان، تقويت 


\section{نتيجه كَيرى}

نتايج مطالعه حاضر نشان داد كه تلاش براى يربارسازى مهارتهاى رابطه بينفردى در مشاركتكنندكان از طريق كمك به بسط سرمايه روانشناختى و منابع روانى_اجتماعى آنها مانند خوشبينى، رفتارهاى مقابلهاى، تاب آورى، مهارگرى روانشناختى، حرمت خود، تحمل ابهام و حمايت اجتماعى و متعاقب آن توانمندسازى افراد براى كاستن از تجارب متعارض، سازشيافتگى با رخدادها و واقعيات منفى، حفظ خودينداشت مثبت، حفظ تعادل هيجانى و تداوم روابط رضايتبخش با باديا ديكران، مصونيت روانى دانشآموزان دختر را موجب مى شود.

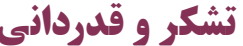

مقاله حاضر بر گَرفته از ياياننامه كارشناسى ارشد نويسنده اول است. از مديريت محترم دبيرستان دوره اول متوسطه شاهد كوثر شهرستان

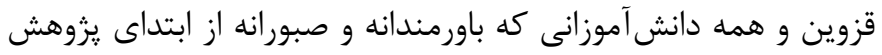
تا انتها محقق را يارى كردند، كمال تشكر و قدردانى را دارم.

\section{References}

1. Labrague LJ, McEnroe-Petitte DM. An integrative review on conflict management styles among nursing students: Implications for nurse education. Nurse Education Today. 2017;59:45-52.

2. Waithaka AG, Moore-Austin S, Gitimu PN. Influence of conflict resolution training on conflict handling styles of college students. Research in Higher Education Journal. 2015;28:1-17. 3. Ayas T, Deniz M, Kağan M, Kenç MF. An investigation of conflict resolution strategies of adolescents. Procedia-Social and Behavioral Sciences. 2010;2(2):3545-3551.

4. Branje SJ, Van Doorn M, van der Valk I, Meeus W. Parentadolescent conflicts, conflict resolution types, and adolescent adjustment. Journal of Applied Developmental Psychology. 2009;30(2):195-204.

5. Collie RJ, Martin AJ, Papworth B, Ginns P. Students' interpersonal relationships, personal best (PB) goals, and academic engagement. Learning and Individual Differences. 2016;45:65-76. 6. Ryan AM, Shim SS. An exploration of young adolescents' so-
مهارتآموزى براى ايجاد و تداوم روابط با ديخران از اهميت ويزهاى برخوردار است. مهارتهاى بين فردى مورد نياز شامل عزت نفس و خودآكاهى فزونى يافته، مهارتهاى تفكر منطقى، واقع گرا، منعطف، خلاق، فعالانه و مثبت و همجنين هوش هيجانى_اجتماعى است. به

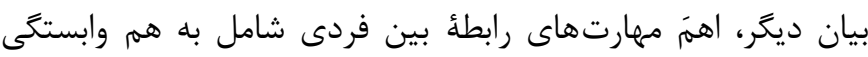
در روابط، ادراى مثبت از ديخران، احساسات مثبت براى ديكران، هدف هاى برد_برد در روابط، مهارتهاى مديريت مبتنى بر تشريك مساعى موقعيتهاى متعارض و مهارتهاى تعامل بين فردى است. علاوه بر اين، هر گونه بى توجهى به توانمندسازى كودكان و نوجوانان به ويزه كودكان و نوجوانانى كه استعداد نمايش گسترهٔ وسيعى از رفتارهاى ناساز Fارانه را در تعامل با همسالان خود نشان مى دهند، زمينه را براى ظهور اشكال ييجيدهترى از رفتارهاى بزهكارانهٔ آتى را سبب خواهد شد. بنابراين، توسعهُ بيش از ييش تلاش هاى آموزشى_ملاخلهاى براى كودكان با هدف كاهش رفتارهاى ناسازكارانه در آنها بدون شك در ييشخيرى از آسيب هاى اجتماعى متعاقب نقش مهمىى را ايفا مى كند.

cial achievement goals and social adjustment in middle school. Journal of Educational Psychology. 2008;100(3):672-678.

7. Pajkic I. Impact of parent -adolescent conflict on adolescents' well-being [PhD Dissertation]. Melbourne:RMIT University;2013.

8. Şahin FS, Serin NB, Serin O. Effect of conflict resolution and peer mediation training on empathy skills. Procedia-Social and Behavioral Sciences. 2011;15:2324-2328.

9. Turnuklu A, Kacmaz T, Sunbul D, Ergul H. Does peer-mediation really work? effects of conflict resolution and peer-mediation training on high school students' conflicts. Procedia-Social and Behavioral Sciences. 2009;1(1):630-638.

10. Colsman M, Wulfert E. Conflict resolution style as an indicator of adolescents' substance use and other problem behaviors. Addictive Behaviors. 2002;27(4):633-648.

11. Illeris K. The three dimensions of learning. Malabar:Krieger Publishing Company;2002.

12. Illeris K. Towards a contemporary and comprehensive the- 
ory of learning. International Journal of Lifelong Education. 2003;22(4):296-406.

13. Halperin E, Tagar MR. Emotions in conflicts: Understanding emotional processes sheds light on the nature and potential resolution of intractable conflicts. Current Opinion in Psychology. 2017; 17:94-98.

14. Crick NR, Dodge KA. A review and reformulation of social information-processing mechanisms in children's social adjustment. Psychological Bulletin. 1994;115(1):74-101.

15. Dodge KA. Translational science in action: Hostile attributional style and the development of aggressive behavior problems. Development and Psychopathology. 2006;18(3):791-814. 16. Dodge KA, Coie JD, Lynam D. Aggression and antisocial behavior in youth. In: Handbook of Child Psychology. Hoboken NJ:John Wiley \& Sons, Inc;2007.

17. Dodge KA, Pettit GS. A biopsychosocial model of the development of chronic conduct problems in adolescence. Developmental Psychology. 2003;39(2):349-371.

18. Ryff CD. Happiness is everything, or is it? Explorations on the meaning of psychological well-being. Journal of Personality and Social Psychology. 1998;57(6):1069-1081.

19. Lopes PN, Salovey P, Straus R. Emotional intelligence, personality, and the perceived quality of social relationships. Personality and Individual Differences. 2003;35(3):641-658.

20. Springer KW, Hauser RM, Freese J. Bad news indeed for Ryff's six-factor model of well-being. Social Science Research. 2006;35(4):1120-1131.

21. Ryff CD, Singer B. Best news yet on the six-factor model of well-being. Social Science Research. 2006;35(4):1103-1119.

22. Campbell RJ. Campbell's psychiatric dictionary. Oxford:Oxford University Press;2009.

23. Karimifar M, Dinparvar E, Rouholamini MS, Besharat MA. The effectiveness of teaching emotion regulation based on gross model on the amount of social and emotional adaptation among young men. Advances in Cognitive Sciences. 2017;19(1):25-37. (Persian)

24. Tanyi ME. The student's adjustment inventory manual. IFE
Psychologia: An International Journal. 2002;10(1):1-14.

25. Schick A, Cierpka M. Faustlos: Evaluation of a curriculum to prevent violence in elementary schools. Applied and Preventive Psychology. 2005;11(3):157-165.

26. Kam CM, Greenberg MT, Kusché CA. Sustained effects of the PATHS curriculum on the social and psychological adjustment of children in special education. Journal of Emotional and Behavioral Disorders. 2004;12(2):66-78.

27. Domitrovich CE, Cortes RC, Greenberg MT. Improving young children's social and emotional competence: A randomized trial of the preschool "PATHS" curriculum. The Journal of Primary Prevention. 2007;28(2):67-91.

28. Crean HF, Johnson DB. Promoting Alternative Thinking Strategies (PATHS) and elementary school aged children's aggression: Results from a cluster randomized trial. American Journal of Community Psychology. 2013;52(1-2):56-72.

29. Fraser MW, Thompson AM, Day SH, Macy RJ. The Making Choices program: Impact of social-emotional skills training on the risk status of third graders. The Elementary School Journal. 2014;114(3):354-379.

30. Webster-Stratton C, Reid J. Strengthening social and emotional competence in young children-the Foundation for early school readiness and success. Infants and Young Children. 2004;17(2):96-113.

31. Bergeron JL, Nolan RF, Dai Y, White B. Interpersonal skills training with at-risk high school students. National Forum of Applied Educational Research Journal. 2013;26(3):1-10.

32. Patterson DS, Jolivette K, Crosby S. Social skills training for students who demonstrate poor self-control. Beyond Behavior. 2006;15(3):23-27.

33. Fraser MW, Day SH, Galinsky MJ, Hodges VG, Smokowski PR. Conduct problems and peer rejection in childhood: A randomized trial of the making choices and strong families programs. Research on Social work Practice. 2004;14(5):313-324. 34. Fraser MW, Lee JS, Kupper LL, Day SH. A controlled trial of the Making Choices program: Six-month follow-up. Research on Social Work Practice. 2011;21(2):165-176. 
35. Van Dierendonck D. The construct validity of Ryff's Scales of Psychological Well-being and its extension with spiritual well-being. Personality and Individual Differences. 2004;36(3):629-643.

36. Shokri O, Kadivar P, Farzad V, Daneshvarpour Z, Dastjerdi R, Paeezi M. A study of factor structure of 3, 9 and 14-item Persian versions of Ryff's Scales Psychological Well-being in university students. Iranian Journal of Psychiatry and Clinical Psychology. 2008;14(2):152-161. (Persian)

37. Sinha A, Singh R. The adjustment Inventory for school students (AISS). Agra (India): National Psychological Corporation;1993.

38. Karami A. High School Student Adaptation Questionnaire Guide. Tehran:Sinai Institute of Psychiatry;1998. (Persian)

39. Golestan Jahromi F, Shahani Yeylagh M, Behrozi N, Omidiyan M. The effect of bullying prevention program training on bullying, adjustment and empathy among middle school female students. Journal of Cognitive Strategies of Learning. 2017;5(8):183-204. (Persian)

40. Bagherzade S, Hosseini Tabaghdehi L, Hafezian M. Relationship of self-awareness and self-regulated learning to social adjustment among girl high school students. Journal of Educational Psychology Studies. 2018;15(30):29-50. (Persian)

41. Khalifa WAS. The effectiveness of a training program based on Dodge's Social Information Processing Model on social competence of children with ADHD. International Journal of Psycho-Educational Sciences. 2013;2(1):126-137.

42. Arsenio WF, Lemerise EA. Emotions, aggression, and morality in children: Bridging development and psychopathology. Washington:American Psychological Association;2010.

43. Gaitoani M. Children and adolescent maladjustment. (Bazargan Z, Trans). Tehran:Sokhan;2013. (Persian)

44. Pianta RC, Stuhlman MW. Teacher-child relationships and children's success in the first years of school. School Psychology Review. 2004;33(3):444-358.

45. Baker JA. Contributions of teacher-child relationships to positive school adjustment during elementary school. Journal of School Psychology. 2006;44(3):211-229.

46. Lent RW, Taveira MC, Sheu H-B, Singley D. Social cognitive predictors of academic adjustment and life satisfaction in Portuguese college students: A longitudinal analysis. Journal of Vocational Behavior. 2009;74(2):190-198.

47. Cazan AM. Self-regulated learning strategies-predictors of academic adjustment. Procedia-Social and Behavioral Sciences. 2012;33:104-108.

48. Pourrazvi SS, Hafezian M. The effectiveness of teaching positive thinking skills on social, emotional, and academic adjustment of high school students. Journal of School Psychology. 2017;6(1):26-48. (Persian)

49. Tamannaeifar MR, Mansourinik A. The relationship between personality characteristics, social support and life satisfaction with university students' academic performance. Quarterly Journal of Research and Planning in Higher Education. 2014;20(1):149-166. (Persian)

50. Jaffee SR, Caspi A, Moffitt TE, Polo-Tomas M, Price TS, Taylor A. The limits of child effects: Evidence for genetically mediated child effects on corporal punishment but not on physical maltreatment. Developmental Psychology. 2004;40(6):1047-1058.

51. Mercer SH, DeRosier ME. Teacher preference, peer rejection, and tudent aggression: A prospective study of transactionalinfluence and independent contributions to emotional adjustment and grades. Journal of School Psychology. 2008;46(6):661-685.

52. Heaven PC, Ciarrochi J, Vialle W. Self-nominated peer crowds, school achievement, and psychological adjustment in adolescents: Longitudinal analysis. Personality and Individual Differences. 2008;44(4):977-988.

53. Buhs ES. Peer rejection, negative peer treatment, and school adjustment: Self-concept and classroom engagement as mediating processes. Journal of School Psychology. 2005;43(5):407-424.

54. Li J, Fraser MW, Wike TL. Promoting social competence and preventing childhood aggression: A framework for apply- 
ing social information processing theory in intervention research. Aggression and Violent Behavior. 2013;18(3):357-364. 55. Dawood R. Positive psychology and child mental health; A premature application in school-based psychological intervention. Procedia-Social and Behavioral Sciences. 2014;113(7):44-53.

56. Desai M. A rights-based preventative approach for psychosocial well-being in childhood: Children's well-being. Indicators and Research:Mumbai Springer;2010.

57. Dincyurek S, Civelek AH. The determination of the conflict resolution strategies of university students that they use when they have conflicts with people. Behavior Analyst Today. 2008;9(3-4):215-233.

58. Morrison M, Shaw Austad C, Cota K. Help increase the peace, a youth-focused program in peace education. Journal of Peace Education. 2011;8(2):177-191.

59. Bush RA, Folger JP. The promise of mediation: Responding to conflict through empowerment and recognition. San Francisco:Jossey-Bass;1994.

60. Simerly RG. Managing conflict for productive results: A critical leadership skill. The Journal of Continuing Higher Education. 1998;46(2):2-11.

61. Heckenlaible-Gotto MJ, Roggow L. Supporting peers lives and solving hassles: The SPLASH program. Reclaiming Children and Youth. 2007;15(4):220-226.

62. Laursen EK. Rather than fixing kids-build positive peer cultures. Reclaiming Children and Youth. 2005;14(3):137-142.
63. Opp G, Unger N, Teichmann J. Together, not alone: Positive peer culture in a German school. Reclaiming Children and Youth. 2007;15(4):234-242.

64. Gresham FM, Van MB, Cook CR. Social skills training for teaching replacement behaviors: Remediating acquisition deficits in at-risk students. Behavioral Disorders. 2006;31(4):363-377.

65. Conroy MA, Hendrickson JM, Hester PP. Early identification and prevention of emotional and behavioral disorders. In Rutherford Jr R, Quinn MM, Mathur SR, editors. Handbook of research in emotional and behavioral disorders. New York:The Guilford Press; 2004. pp. 199-215.

66. Vespo IE, Capece D, Behforooz B. Effects of the nurturing curriculum on social, emotional, and academic behaviors in kindergarten classrooms. Journal of Research in Childhood Education. 2006;20(4):275-285.

67. Johns B, Crowley EP, Guetzloe E. The central role of teaching social skills. Focus on Exceptional Children. 2005;37(8):1-8. 68. Kavale KA., Mathur SR, Mostert MP. Social skills training and teaching social behavior to students with emotional and behavioral disorders. In Rutherford Jr R, Quinn MM, Mathur SR, editors. Handbook of research in emotional and behavioral disorders. New York:The Guilford Press;2004. pp. 446-461 69. Kheradmand S, Jalal M, Shamsesfandabad H. Comparison cognitive empathy and emotional empathy in assertive individuals and individuals with antisocial personality style. Advances in Cognitive Sciences. 2018;20(3):114-126. (Persian) 